\title{
Anemia in new born
}

\author{
Kishore Kumar $\mathrm{R}^{1 *}$, Nandini Nagar ${ }^{2}$ and Prashanth Sarnadgouda ${ }^{3}$ \\ ${ }^{1}$ Consultant Neonatologist and Paediatrician, Cloudnine Hospitals, Bangalore, India, Adjunct Professor in Neonatology \& Paediatrics, Notre Dame University, \\ Perth, Australia \\ ${ }^{2}$ Consultant Neonatologist, Cloudnine Hospital, Jayanagar, Bangalore \\ ${ }^{3}$ Neonatologist and Paediatrician, Cloudnine Hospital, Jayanagar, Bangalore
}

\section{Introduction}

Anemia in the new born is the commonest hematological problem. Immediately following birth, all infants universally experience a decrease in hemoglobin $(\mathrm{Hb})$ that results in varying degrees of anemia. The ultimate severity and rapidity with which this anemia develops are determined by a combination of multiple physiologic and nonphysiologic processes. Preterm infants are especially vulnerable to these processes for two reasons. Firstly, the severity of the developmental postnatal decrease in $\mathrm{Hb}$ is most pronounced in the least mature infants, placing them at higher risk of developing clinically significant anemia. Secondly, as a group, preterm infants are particularly prone to developing electrolyte and acid-base imbalance, and infective illnesses, the diagnosis and management of which requires frequent laboratory assessment, resulting in significant phlebotomy loss. It is the combination of developmentally regulated physiologic processes (anemia of prematurity [AOP]) along with concomitant pathologic and iatrogenic processes that contribute to the progressive anemia experienced by virtually all preterm infants.

The causes of anemia in newborns can be prenatal, natal or postnatal. Usually the diagnosis will be straight forward if approached in a systematic manner. The objective of this review is to discuss the physiology, the causes, clinical presentation and approach to the newborn anemia.

\section{Physiology}

The process of haematopoiesis begins as early as $3^{\text {rd }}$ week of gestation in the yolk sac [1]. From 11-12 weeks of gestation, liver is the organ of haematopoiesis [2]. Bone marrow erythropoiesis switch happens around 30 weeks of intrauterine life \& at birth, marrow erythropoiesis is major site for blood cells production [3].

In utero, the oxygen saturation in aortic blood is around $45 \%$, erythropoietin levels are high, and red blood cells production is rapid. Soon after birth, the oxygen saturation goes up to $95 \%$, down regulating the erythropoietin mediated red cell production. The erythropoietin will become undetectable by 3 days after birth with reduction in reticulocyte counts and thus haemoglobin levels [4].

At birth the haemoglobin levels is $14.9 \mathrm{~g} / \mathrm{dl}-23.7 \mathrm{~g} / \mathrm{dl}$ in term and $19.1 \mathrm{~g} / \mathrm{dl}-22.1 \mathrm{~g} / \mathrm{dl}$ in preterm babies. It rapidly falls to $9.5-11 \mathrm{~g} / \mathrm{dl}$ by 9-11 weeks of postnatal period in term babies and $6.5-9 \mathrm{~g} / \mathrm{dl}$ by $4-8$ weeks in preterm babies [5]. After reaching this nadir, the infant's marrow starts its erythropoiesis. The iron released from breakdown of these RBCs is stored in the liver, which in turn is utilised for erythropoiesis. Usually term babies have sufficient iron stores till 5 months of age for active erythropoiesis, after which iron needs to be supplemented by iron rich complementary foods. Preterm babies require iron supplementation from as early as 2-3 weeks of post natal age continued through their first year of life. Simultaneously there is increase in 2,3- diphosphoglycerate in red blood cells as slowly adult haemoglobin $(\mathrm{HbA})$ replaces fetal haemoglobin $(\mathrm{HbF})$ during the first half of infancy [6-8]. HbA has very less affinity for oxygen as compared to $\mathrm{HbF}$, thus even with falling hemoglobin levels, the oxygen delivery to the tissues actually increases.

Preterm babies have added problems like, poor general condition, reduced life span of RBC (35-40 days vs. 60-70 days of term babies) [9], increased phlebotomy losses, accelerated growth rate, poor iron stores and inappropriate bone marrow response making them at the risk of exposure to repeated transfusions. In general, even term neonates with normal haemoglobin at birth would have depleted their iron stores by the time they have doubled their birth weight [10].

\section{The influence of cord clamping}

The other major influence on haemoglobin concentration at birth is the timing of cord clamping and the position of the baby at the time of clamping. In term babies, the placental vessels contain around $100 \mathrm{ml}$ of blood at birth. It has been estimated that $25 \%$ of the placental blood is transfused within the first 15 seconds and $50 \%$ (i.e., $50 \mathrm{ml}$ in a term baby) by the end of the first minute [11]. The difference in hemoglobin concentration in the baby between early and late cord clamping is around $3 \mathrm{~g} / \mathrm{dl}$ [12]. Babies held below the level of the placenta continue to gain blood until the cord is clamped and have higher haemoglobin levels than those held above the level of the placenta, who may lose blood into the placenta until the cord is clamped [13].

\section{Causes}

1. Impaired red cell production

Diamond-Blackfan anaemia

Congenital infection, e.g. cytomegalovirus, rubella

Congenital dyserythropoietic anaemia

Osteopetrosis

Correspondence to: Kishore Kumar, Consultant Neonatologist and Paediatrician, Cloudnine Hospitals, Adjunct Professor in Neonatology and Paediatrics, Notre Dame University, Perth, Australia, Tel: + 91806673 2259; Fax: + 91804020 2233; E-mail: drkishore@cloudninecare.com

Received: June 02, 2016; Accepted: July 04, 2016; Published: July 08, 2016 
Pearson syndrome

Congenital leukaemia

Drug induced suppression

2. Increased red cell destruction (haemolysis)

Alloimmune: haemolytic disease of the newborn (Rh, ABO, Kell, others)

Autoimmune, e.g. maternal autoimmune haemolysis

Red cell membrane disorders, e.g. hereditary spherocytosis

Red cell enzyme deficiencies, e.g. pyruvate kinase deficiency, G6PD deficiency

Some hemoglobinopathies, e.g. $\alpha$-thalassemia major, $\mathrm{HbH}$ disease

Infection, e.g. bacterial, syphilis, malaria, cytomegalovirus,

Toxoplasma, herpes simplex

Macro/microangiopathy, e.g. cavernous haemangioma, disseminated intravascular coagulation

Galactosaemia, vitamin E deficiency

3. Blood loss

Occult haemorrhage before or around birth, e.g. twin-to-twin, fetomaternal, ruptured vasa praevia, abruption placenta, placenta previa, cord rupture

Internal haemorrhage, e.g. intracranial, subaponeurotic, Intraperitoneal, ruptured liver/ spleen, adrenal hemorrhage, NEC

Iatrogenic: due to frequent blood sampling

4. Anaemia of prematurity

Impaired red cell production plus reduced red cell lifespan

\section{Clinical manifestations}

A detailed antenatal history including records of antenatal sonological reports gives a lot of information. Twin-twin transfusion can very well be diagnosed antenatally. Obtaining a peak systolic velocity of middle cerebral artery gives an indirect estimation of anemia as well as a guide to antenatal therapy [13]. Details of labour, presentation, instrumental delivery, birth injury, cord accidents and other details should be collected.

Family history of anemia, cholelithiasis, splenectomy, unexplained jaundice may point towards a possible haemolytic anemia. Any medication given to the baby must be checked.

Presentation can vary from being asymptomatic to hydrops and congestive cardiac failure. Chronic anemia can present as pallor without much distress whereas acute blood loss presents in shock in presence of normal $\mathrm{Hb}$ values. Unexplained tachycardia, oxygen requirement, prolonged unconjugated jaundice, not gaining adequate weight are very non-specific symptoms. Presence of hepatospleenomegaly may point for haemolytic jaundice or congenital infections. Congenital infections in addition can have chorioretinitis, pneumonitis, osteoarthritis, IUGR etc. Congenital anemia syndromes will have skeletal abnormalities.

\section{Evaluation}

1. Complete hemogram including, haemoglobin levels, retic count, peripheral smear study, red blood cell count, RBC indices should be evaluated. The values must be interpreted in the background
Table 1. Differential diagnosis and management of anemia in the newborn.

\begin{tabular}{|c|c|c|c|c|}
\hline Age & Hemoglobin (g/dl) & Hematocrit (\%) & $\operatorname{Mcv}(\mu 3)$ & Reticulocytes (\%) \\
\hline \multicolumn{5}{|c|}{ Gestational (wk) } \\
\hline $18-20^{*}$ & $11.5+/-0.8$ & $36+/-3$ & $134+/-8.8$ & $\mathrm{~N} / \mathrm{a}$ \\
\hline $21-22 *$ & $12.3+/-0.9$ & $39+/-3$ & $130+/-6.2$ & $\mathrm{~N} / \mathrm{a}$ \\
\hline $23-25^{*}$ & $12.4+/-0.8$ & $39+/-2$ & $126+/-6.2$ & $\mathrm{~N} / \mathrm{a}$ \\
\hline $26-27$ & $19.0+/-2.5$ & $62+/-8$ & $132+/-14.4$ & $9.6+/-3.2$ \\
\hline $28-29$ & $19.3+/-1.8$ & $60+/-7$ & $131+/-13.5$ & $7.5+/-2.5$ \\
\hline $30-31$ & $19.1+/-2.2$ & $60+/-8$ & $127+/-12.7$ & $5.8+/-2.0$ \\
\hline $32-33$ & $18.5+/-2.0$ & $60+/-8$ & $123+/-15.7$ & $5.0+/-1.9$ \\
\hline $34-35$ & $19.6+/-2.1$ & $61+/-7$ & $122+/-10.0$ & $3.9+/-1.6$ \\
\hline $36-37$ & $19.2+/-1.7$ & $64+/-7$ & $121+/-12.5$ & $4.2+/-1.8$ \\
\hline $38-40$ & $19.3+/-2.2$ & $61+/-7$ & $119+/-9.4$ & $3.2+/-1.4$ \\
\hline \multicolumn{5}{|c|}{ Postnatal (days) } \\
\hline 1 & $19.0+/-2.2$ & $61+/-7$ & $119+/-9.4$ & $3.2+/-1.4$ \\
\hline 2 & $19.0+/-1.9$ & $60+/-6$ & $115+/-7.0$ & $3.2+/-1.3$ \\
\hline 3 & $18.7+/-3.4$ & $62+/-9$ & $116+/-5.3$ & $2.8+/-1.7$ \\
\hline 4 & $18.6+/-2.1$ & $57+/-8$ & $114+/-7.5$ & $1.8+/-1.1$ \\
\hline 5 & $17.6+/-1.1$ & $57+/-7$ & $114+/-8.9$ & $1.2+/-0.2$ \\
\hline 6 & $17.4+/-2.2$ & $54+/-7$ & $113+/-10.0$ & $0.6+/-0.2$ \\
\hline 7 & $17.9+/-2.5$ & $56+/-9$ & $118+/-11.2$ & $0.5+/-0.4$ \\
\hline \multicolumn{5}{|c|}{ Postnatal (wk) } \\
\hline $1-2$ & $17.3+/-2.3$ & $54+/-8$ & $112+/-19.0$ & $0.5+/-0.3$ \\
\hline $2-3$ & $15.6+/-2.6$ & $46+/-7$ & $111+/-8.2$ & $0.8+/-0.6$ \\
\hline $3-4$ & $14.2+/-2.1$ & $43+/-6$ & $105+/-7.5$ & $0.6+/-0.3$ \\
\hline $4-5$ & $12.7+/-1.6$ & $36+/-5$ & $101+/-8.1$ & $0.9+/-0.8$ \\
\hline $5-6$ & $11.9+/-1.5$ & $36+/-6$ & $102+/-10.2$ & $1.0+/-0.7$ \\
\hline $6-7$ & $12.0+/-1.5$ & $36+/-5$ & $105+/-12.0$ & $1.2+/-0.7$ \\
\hline $7-8$ & $11.1+/-1.1$ & $33+/-4$ & $100+/-13.0$ & $1.5+/-0.7$ \\
\hline $8-9$ & $10.7+/-0.9$ & $31+/-3$ & $93+/-12.0$ & $1.8+/-1.0$ \\
\hline $9-10$ & $11.2+/-0.9$ & $32+/-3$ & $91+/-9.3$ & $1.2+/-0.6$ \\
\hline $10-11$ & $11.4+/-0.9$ & $34+/-2$ & $91+/-7.7$ & $1.2+/-0.7$ \\
\hline $11-12$ & $11.3+/-0.9$ & $33+/-3$ & $88+/-7.9$ & $0.7+/-0.3$ \\
\hline $12-14$ & 11.9 & 37 & 86.8 & 0.9 \\
\hline
\end{tabular}

of normal range (Table 1 and 2) (capillary sample Hct is $2.7 \%-3.9 \%$ higher than venous) [14]. Hb value of less than $14 \mathrm{gms} \%$ in the first week of life is considered anemia in newborn period [15].

2. MCV values will be more in newborn period (105-125fl $v s$. $75-90 \mathrm{fl}$ in children). A value of less than $95 \mathrm{fl}$ is considered as microcytic. $\mathrm{MCH}$ is also more till 8-10 weeks of postnatal age (35-38 pg vs. 30-33 pg). hypochromia is when MCH is less than $34 \mathrm{pg}$ [16]. Microcytic and hypochromic is commonly seen with chronic hemolysis, blood loss or thalassemia disorders $\left({ }^{\mathrm{L}}\right.$ and $\gamma$ thalassemia).

3. Reticulocyte counts in children and adult are $1 \%-2 \%$. In term babies the reticulocyte counts are $3 \%-7 \%$ which falls to $1 \%$ by the end of first week of life. Preterm babies will have slightly more number (6\%$10 \%)$ as also persists till 2-3 weeks of life [17].

4. Nucleated RBCs are also markers of hemolysis in the absence of asphyxia. They are normally not detectable in the peripheral circulation beyond first week of life in term babies, though in preterm babies they can persist up to 4 weeks.

5. Peripheral smear examination- look for the evidence of hemolysis, spherocytosis, elliptocytes other size and shape of red blood cells. Decreased cells indicate a hypo plastic/aplastic condition which may be a primary or secondary aplastic anemia. Presence of abnormal cells may indicate congenital leukaemias. 
Table 2. Effects of early erythropoietin therapy.

\begin{tabular}{|c|c|c|c|}
\hline Hematocrit (\%) & Hemoglobin (g/dl) & Respiratory support and/or symptoms & Transfusion volume \\
\hline$\leq 35$ & $\leq 11$ & $\begin{array}{l}\text { Infants requiring moderate or significant mechanical ventilation (mean arterial pressure }>8 \mathrm{~cm} \mathrm{~h}_{2} \mathrm{O} \\
\text { and fio }>0.4 \text { ) }\end{array}$ & $15 \mathrm{ml} / \mathrm{kg}$ prbcs* over $2-4 \mathrm{hr}$ \\
\hline$\leq 30$ & $\leq 10$ & $\begin{array}{l}\text { Infants requiring minimal respiratory support (any mechanical ventilation or endotracheal/nasal } \\
\text { continuous positive airway pressure }>6 \mathrm{~cm} \mathrm{~h}_{2} \mathrm{O} \text { and } \mathrm{fio}_{2} \leq 0.4 \text { ) }\end{array}$ & $15 \mathrm{ml} / \mathrm{kg}$ prbcs over $2-4 \mathrm{hr}$ \\
\hline$\leq 25$ & $\leq 8$ & $\begin{array}{l}\text { Infants not requiring mechanical ventilation but who are receiving supplemental o } 2 \text { or cpap with an } \\
\text { fio } 2 \leq 0.4 \text { and in whom } 1 \text { or more of the following is present: } \\
\text { - } \leq 24 \mathrm{hr} \text { of tachycardia (heart rate }>180 \text { beats } / \text { min) or tachypnea (respiratory rate }>80 \\
\text { breaths } / \text { min) } \\
\text { An increased oxygen requirement from the previous } 48 \mathrm{hr} \text {, defined as a } \geq 4 \text {-fold } \\
\text { increase in nasal canula flow (i.e., from } 0.25 \text { to } 1 \mathrm{l} / \mathrm{min} \text { ) or an increase in nasal cpap } \\
\geq 20 \% \text { from the previous } 48 \mathrm{hr} \text { (i.e., } 5 \text { to } 6 \mathrm{~cm} \mathrm{~h} 2 \mathrm{o} \text { ) } \\
\text { Weight gain }<10 \mathrm{~g} / \mathrm{kg} / \text { day over the previous } 4 \text { days while infant is receiving } \geq 100 \\
\mathrm{kcal} / \mathrm{kg} / \text { day } \\
\text { An increase in episodes of apnea and bradycardia ( }>9 \text { episodes in a } 24 \text {-hr period or } \\
\geq 2 \text { episodes in } 24 \mathrm{hr} \text { requiring bag and mask ventilation) while infant is receiving } \\
\text { therapeutic doses of methylxanthines } \\
\text { Undergoing surgery }\end{array}$ & $\begin{array}{l}20 \mathrm{ml} / \mathrm{kg} \text { prbcs over } 2-4 \mathrm{hr} \text { (divide into } 210-\mathrm{ml} / \mathrm{kg} \\
\text { volumes if infant is fluid sensitive) }\end{array}$ \\
\hline$\leq 20$ & $\leq 7$ & Asymptomatic and an absolute reticulocyte count $<100,000$ cells $/ 1$ & $20 \mathrm{ml} / \mathrm{kg}$ prbcs over $2-4 \mathrm{hr}$ (2 10-ml/kg volumes) \\
\hline
\end{tabular}

6. Direct antiglobulin test (DAT)/ direct coomb's test (DCT) - detects the presence of antibody coated red blood cells. It is positive in cases of isoimmunisation due to $\mathrm{Rh}$ incompatibility and in less proportion of isoimmunisation due to $\mathrm{ABO}$, Kell or other minor blood group incompatibilities.

7. Enzyme assay for G6PD deficiency, pyruvate kinase deficiencies.

8. Haemoglobin electrophoresis requires expertise for interpretation as the predominant fetal haemoglobin $(\mathrm{HbF})$ will get replaced by adult haemoglobin $(\mathrm{HbA})$ during the early neonatal period.

9. Kleihauer-Betke test or by flow cytometry methods - fetal cells in maternal blood can be detected in cases of feto-maternal transfusions.

10. Congenital parvo viral infection can be diagnosed by PCR method.

11. Imaging studies for occult bleeding into organs should be considered when history and clinical examinations are suggestive of the same.

12. Congenital syndromes like Diamond Blackfan anemia, Pearson syndrome, congenital dyserythropoietic anemia, may require bone marrow examination and other specific tests.

\section{Management}

The widely practiced treatment option for anemia in infants is packed red cells transfusion. There are guidelines for transfusions in neonates. Many trials have compared the benefits and adverse outcomes of 'restricted' versus 'liberal' approach for transfusion.

\section{Red blood cells transfusion}

Packed red blood cells are the product of choice for transfusion when indicated. 10-15 ml/kg of PRBC transfusion is recommended over a period of 3-4 hours. Each $3 \mathrm{ml} / \mathrm{kg}$ of transfused PRBC raises $\mathrm{Hb}$ levels by $1 \mathrm{gm} \%$. In cases of hemorrhagic shock whole blood transfusions can be considered if available. In a small study of 30 transfusions in 13 infants (birth weight 500-1500 g), comparing 10 vs. $20 \mathrm{ml} / \mathrm{kg}$, it was found that the use of a larger volume $(20 \mathrm{ml} / \mathrm{kg})$ results in a higher post-transfusion $\mathrm{Hb}$ without negative respiratory effects [18]. Blood currently available in most of the blood bank is Citrate-PhosphateDextrose (CPD), or CPD-adenine (CPDA-1) or adenine-saline (AS-3) with a half-life of $21,35 \& 42$ days respectively. Older blood has more potassium along with reduced 2, 3 - DPG levels. Fresh blood within 4-5 days is desirable. Designation of a single AS-3 preserved red cell donation for use by one neonate is an effective way to limit the donor exposure and transfusion associated risks [19].

Leukocyte filtration- all the donors must be screened and ensured that they are CMV infection free. Preterm babies are at a higher risk of acquiring transfusion related infection particularly CMV as they lack immunity. The effective way to reduce the risk of CMV transmission is by using leukocyte filters [20].

Irradiation- the risk of graft versus host disease (GVHD) is highest in preterm babies. It should be ensured that all the transfusions to preterm babies must be irradiated. The half-life of RBC which is irradiated gets reduced by $4-5$ days and there may be risk of hyperkalemia. Currently there is no recommendation to use the irradiated PRBC in term baby transfusions [21,22].

In addition, several recentstudies found an increased risk for necrotizing enterocolitis (NEC) in neonates after RBC transfusions, so-called 'transfusion-associated NEC.' Whether transfusionassociated NEC reflects a causal relation between blood transfusions and the development of NEC or only an indirect association is still controversial. Transfusion-related lung injury, acute respiratory distress with lung infiltrations, is a well-known complication in adult transfusion medicine. It has also been recognized in children but has hardly been described in neonates.

A recent Cochrane review evaluated the results of four randomized controlled trials with a total of 614 infants, comparing lower (restrictive) versus higher (liberal) transfusion thresholds in preterm infants. In this meta-analysis, no significant differences were found in mortality or severe neonatal morbidity, or in long-term neurodevelopmental outcome between the two groups. 


\section{Erythropoietin- (rHuEPO)}

Many studies have shown that preterms treated with $\mathrm{rHuEPO}$ will have less number of transfusions and hence less risk of transfusion associated problems. There are studies comparing early $(<7$ days) versus late rEPO treatment. rHuEPO doesn't reduce the number of transfusions required by preterm babies in early neonatal life where as the late requirement of transfusions can be reduced significantly. Moreover the dose required may be higher upto 250-300 IU/kg, thrice a week; it also requires iron supplementation of $2-3 \mathrm{mg} / \mathrm{kg} /$ day. There is also concern over the increased incidence of ROP in premature babies treated with $\mathrm{rHuEPO}$ in early life.

\section{Financial Disclosure}

The authors have indicated they have no financial relationships relevant to this article to disclose.

\section{Conflict of Interest}

The authors have no potential conflicts of interest to disclose.

\section{Clinical Trial Registration}

Not applicable.

\section{Contributors' Statements}

Dr R. Kishore Kumar: conceptualized and designed the study, critically analysed the manuscript, and approved the final manuscript as submitted. Dr Nandini Nagar: Dr. Nandini wrote the initial draft, reviewed and revised the manuscript, and approved the final manuscript as submitted. Dr Prashanth Sarnadgoud was involved in collecting data, drafting the initial manuscript and approving the final manuscript. All authors approved the final manuscript as submitted and agree to be accountable for all aspects of the work.

\section{References}

1. Huyhn A, Dommergues M, Izac B (1995) Characterization of hematopoietic progenitors from human yolk sacs and embryos. Blood 86: 4474-4485.

2. Marshall CJ, Thrasher AJ (2001) The embryonic origins of human haematopoiesis. $\mathrm{Br}$ J Haematol 112: 838-850. [Crossref]

3. Tavian M, Hallais MF, Péault B (1999) Emergence of intraembryonic hematopoietic precursors in the pre-liver human embryo. Development 126: 793-803. [Crossref]

4. Bifano EM, Ehrenkranz Z (1995) Perinatal hematology. Clinical Perinatology 23.

5. Oski FA (1993) The erythrocyte and itsdisorders. In: Nathan, A., Oski, F.A. (Eds.), Hematology of Infancy and Childhood.WB Saunders, Philadelphia 18-43.

6. Blanchette V, Doyle J (1994) hematology. In: Avery GB, Fletchre MA, Neonatology. 4thedi, Philadelphia: Lippincott- raven publishers 952-999

7. Glader B, Naiman JL (1991) Erythrocyte disorder in infancy. Diseases of new born, Philadelphia: WB Saunders

8. Nathan DG, Oski FA (1993) Hematology of infancy 4th edition. Philadelphia: WB Saunders.

9. Pearson HA (1967) Life-span of the fetal red blood cell. J Pediatr 70: 166-171. [Crossref]

10. Rao R, Georgieff MK (2002) Perinatal aspects of iron metabolism. Acta Paediatr Suppl 91: 124-129. [Crossref]

11. Linderkamp O, Nelle M, Kraus M, Zilow EP (1992) The effect of early and late cord-clamping on blood viscosity and other hemorheological parameters in full-term neonates. Acta Paediatr 81: 745-750. [Crossref]

12. Yao AC, Lin J, Tiisala R (1969) Placental transfusion in the prematureinfant with observation on clinical courseand outcome. Acta Paediatr Scand 58: 561-566.

13. Moise KJ Jr1 (2008) Management of rhesus alloimmunization in pregnancy. Obstet Gynecol 112: 164-176. [Crossref]

14. Thurlbeck SM, McIntosh N (1987) Preterm blood counts vary with sampling site. Arch Dis Child 62: 74-75. [Crossref]

15. Oski FA (1993) The erythrocyte and itsdisorders. In: Nathan, A., Oski, F.A. (Eds.), Hematology of Infancy and Childhood. WB Saunders, Philadelphia 18-43.

16. Christensen (2009) perinatology.

17. Matoth Y, Zaizov R, Varsano I (1971) Postnatal changes in some red cell parameters. Acta Paediatr Scand 60: 317-323. [Crossref]

18. Paul DA, Leef KH, Locke RG, Stefano JL (2002) Transfusion volume in infants with very low birth weight: a randomized trial of 10 versus $20 \mathrm{ml} / \mathrm{kg}$. J Pediatr Hematol Oncol 24: 43-46. [Crossref]

19. Stauss (2000) recommendation for neonatal transfusions.

20. New HV, Stanworth SJ, Engelfriet CP, Reesink HW, McQuilten ZK, et al. (2009) Neonatal transfusions. Vox Sang 96: 62-85. [Crossref]

21. Australian Red Cross Blood Service, New Zealand Blood Service. Guidelines for Gamma Irradiation of Blood Components2003

22. Gibson BE, Todd A, Roberts I, Pamphilon D, Rodeck C, et al. (2004) Transfusion guidelines for neonates and older children. Br J Haematol 124: 433-453. [Crossref]

Copyright: (C2016 Kumar K. This is an open-access article distributed under the terms of the Creative Commons Attribution License, which permits unrestricted use, distribution, and reproduction in any medium, provided the original author and source are credited. 